\title{
ANALYSIS OF CASH FLOWS SME'S RAJUT IN KENDALSARI, TULUSREJO, MALANG CITY
}

\author{
Chalimatuz Sa'diyah \\ Faculty of Economics and Business, University Muhammadiyah Malang, Indonesia \\ Email : chalimatuzsadiyah@umm.ac.id
}

Abstract: This study aims to be able to know and understand the condition of the cash balance and to know and understand the formation of an optimal cash balance, as well as knowing the adequacy of SME's cash flows in Kendalsari, Malang City. This type of research uses case studies, namely research using secondary data. Secondary data used in this study is the history of the establishment of SME's, SME's financial data, and information on product intricacies. The data analysis technique in this study is to use the Orr Miller Model calculation with the aim to be able to find out the Optimal Cash Balance in SME's. The results of the study indicate the lower limit of cash availability for SME's in order to optimize financial performance of Rp. 107,123. Whereas the upper limit of cash should be Rp. 321,396. And the results of the cash flow adequacy ratio show a value of 1.614. Thus the results of this study can be used as a reference for SME's in conducting cash management. Cash optimization is used to maintain cash so as not to experience shortcomings or excess in carrying out its operational activities so that SME's can maximize their financial performance. $A$ ratio of 1 indicates that SME's can cover cash needs without the need to obtain external funding.

Keywords: Determination Of The Optimal Cas, SME's, Miller Orr

\section{Introduction}

\subsection{Background}

The role of Small and Medium Enterprises (SME's) in the economy of a country is very important, SME's symbolize the economic development power of a country. The importance of SME's is mostly related to the designation as the backbone of economic development. The presence of SME's can create initiative, innovation and the entrepreneurial spirit as a whole. The role of SME's can be said to be very important in the national economy, this role is mainly in aspects such as increased employment opportunities, income distribution, rural economic development, and increased non- oil and gas exports. Small and Medium Enterprises (SME's) are important economic business groups in the economy of Malang City. This is due to the fact that Small and Medium Enterprises (SME's) are business sectors that can assist the government in creating employment and have the largest number with significant absorption of the labour force. With the presence of SME's, labour that cannot be accommodated by large companies can be absorbed by SME's.

Innovation is needed by SME's to be able to progress and develop, so that progress and development must be managed effectively and Innovation becomes very important in overcoming the problems of SME's. In the development of 
SME's, big problems often arise, a big problem that occurs in the development of SME's in the economic market is the lack of skills to create something new and trapped by the characteristics of the past, even though change requires SME's to develop businesses in accordance with the change.

\subsection{Problem Formulation}

The formulation of the problem in this study are:

1. How do SME's optimize cash?

2. What are the methods used by SME's to optimize cash?

\subsection{Research Objectives}

The objectives of this study are:

1. Knowing how SME's optimize cash?

2. Know what methods are used by SME's to optimize cash?

\subsection{Benefits and Uses of Research}

The benefits and uses of this study are:

1. For SME's, it can be used as a basis for financial policy regarding cash management.

2. For the next researcher, as reference material for similar research, and can develop similar theories.

\section{Theoritical Review}

\subsection{Theory Review}

The most liquid asset item is cash. Practical liquidity of an asset is measured by its proximity to cash. Then the assets are arranged based on the liquidity. Receivables occupy the second position after cash because only with one step (accounts payable), accounts receivable will turn into cash. Inventory occupies the next position because inventory requires two steps to get to cash. First, inventory is sold in the form of credit (changes to accounts receivable), then the receivables are paid in cash.

\subsubsection{Cash Management}

\subsubsection{Motives for holding cash}

Cash is the most unproductive asset compared to other sets. Because it is viewed from the side of productivity, indeed a minimum asset is a good choice for the company. There are several motives for why companies hold cash: transaction motives, guarding motives, future needs, minimal cash balance (compensating balance). There are 3 things that financial managers want to do when managing cash:

1. Speed up cash income.

2. Slow down cash outlays.

3. Maintain an optimal cash balance.

Increasing cash availability is consistent with the aim of increasing the cash conversion cycle. A small cash cycle (cash conversion cycle) will reduce investment in working capital. The company can thus save investment funds on working capital. In addition, if the time to hold cash is extended, the company has more money to take advantage of the cash, the extension of time can be done by speeding up payments from customers (cash inflows), and / or slowing expenses (to suppliers). Of course in these activities, managers must remember the limitations that need to be known, namely the company's reputation does not go down. Managers may not pay their obligations in order to delay payments, but such methods are certainly unethical and can damage the company's reputation.

\subsubsection{Accelerate Cash Receipts}

Speeding up cash inflows aims to increase cash availability (rather than cash held by other companies, it is better to be held and managed by financial managers). Cash Sales. This method is certainly the most direct method. With cash sales, without accounts, financial managers will get cash. Receivables or credit will only delay cash receipts. But accounts receivable 
or credit sales are sometimes needed to increase sales, and thus increase company profits. Cash deductions. Cash deductions are intended to speed up payment of receivables by the buyer / customer of the company. Term or requirements for cash deductions are usually $1 / 10-\mathrm{n} / 30$.

\subsubsection{Slowing Cash Expenditures}

Slowing down payments has the same goal as speeding up income so that the company has a longer chance to use cash. There are restrictions that must be considered, namely the reputation of the company does not go down due to efforts to slow the cash outflow. The easiest alternative to delaying cash payments is refusing to pay. But of course, the alternative is not feasible, because it will damage the company's reputation. There are several ways to slow down payments.

Credit Purchases. Purchasing with credit means that the supplier marks the first purchase made by the company. The company thus has the opportunity to delay cash disbursement. Usually, credit purchases will be more expensive than cash purchases. Make use of Float. The float is the difference between the cash balance of Rp. 1 million. Then the company issued a check of Rp. 300 thousand. The company's cash balance will be recorded at Rp 700 thousand (Rp 1 million - Rp 300 thousand). But the indirect bank balance becomes Rp 700 thousand because the check is usually not immediately cashed. There is a time limit for cashing a check.

Using Draft. The draft is a payment sign that must be authorized by the company to be paid later. The term cash bond is often used. In case, if there is an invoice, a payment vein will be made, which can only be redeemed a few days later. Another benefit of such methods is to control the company's finances. Central Payments. In this event, every bill that comes to the branch of the company will be submitted to the centre for authorization. After the centre gives an authorization, it is then handed over to the branch and then can be paid. Checks Paid on Certain Days

\section{RESEARCH METHODOLOGY}

\subsection{Location and Time of Research}

The place of research was conducted in Kendalsari Village. The object of the research chosen was the TOP Rajut UMKM. The time of research is conducted from September to December 2018.

\subsection{Types of Research}

This research is a type of descriptive research that is research conducted to find out and explain the characteristics of the variables to be examined in a situation. (Sugiyono, 2013) states that research that uses a quantitative approach will emphasize its analysis on numerical data or numbers that are processed through statistics.

\subsection{Data and Data Sources}

Data is the main input that will be processed in the research process to produce output that will answer the problem and research questions (Abdillah, 2015). According to the understanding, the data distribution is divided into two, namely primary data and secondary data. Secondary data needed as the basis of this research is taken from the data of TOP Rajut's UMKM cash.

\subsection{Data Analysis Techniques}

The data analysis technique used in this study uses the Miller Orr Model calculation to find out the optimal cash balance of MSME TOP Knitting Kendalsari of Malang. 


\section{RESEARCH FINDINGS}

\subsection{Cash Management}

Management of available cash balances is a constant problem in all organizations. This is due to daily cash in and out, either by company activities or negotiated financial transactions. Thus, there is a need to control financial resources to get the best results for the organization (Marcelo Botelho da Costa Moraes, 2014). Cash balances usually fluctuate because of the lack of synchronization between cash inflows (receipts from accounts receivable and cash sales) and outflows (payments on accounts and debt records) (M. Badell, 2005).

A review of previous theoretical works in the literature (Srinivasan, 1986) revealed that while in the field of deterministic models of cash management most of them were developed focusing more on the types of individual financial decisions, on the stochastic cash management model two basic approaches were developed by Baumol (1952) and Miller and Orr (1966). The Baumol model has an inventory approach with certainty assumptions. Cash is treated the same as storing inventory and payments are assumed at a constant level.

Miller's and Orr's cash management procedures are based on the fact that perfect cash estimates are almost impossible to achieve because the time of inflows depends on customer payments. As a result, the lower and upper limits of cash are calculated and set strictly to create safety stock.

4.2 Determining the Optimal Cash Balance of the Company

Miller and Orr (1966) presented a model that met cash flow randomness, although it still considered the existence of only two activations, cash and investment, where the latter represented low-risk options with high liquidity. In this model, two limits are defined for the level of cash balance: lowest and highest, so that, when reaching the maximum level, represented by a higher limit $(\mathrm{H})$, the application of resources is carried out, in the amount that returns the cash balance to the optimal level $(\mathrm{Z})$ And, when it reaches the minimum level at the lower limit (LB), a ransom must be made to obtain an optimal cash level (Ross et al., 2002). Therefore, the definition of the lower limit (LB) has an impact on cash costs and the risks associated with lack of cash, because LB's lack shows companies that do not maintain the background of minimal preventive measures. The Miller-Orr model in this study is calculated through the following formula:

$\mathrm{z}=(3 \mathrm{~b} \sigma 2 / 4 \mathrm{i}) 1 / 3$

$\mathrm{h}=3 \mathrm{z}$

$\mathrm{C}=4 \mathrm{Z} / 3$

Where $\mathrm{z}=$ the lower limit to be searched

$\mathrm{h}=$ upper limit

$\mathrm{b}=$ transaction costs (fixed) securities purchase / sale

$\sigma 2=$ daily net cash flow variance

$\mathrm{i}=$ daily interest rate on securities

$\mathrm{C}=$ average cash balance

The variance of daily net cash flow is Rp. 2,654 , the interest rate is $6 \%$ per year, the purchase / sale transaction cost of the secured letter is Rp. Then the upper and lower limits can be calculated as follows: (Daily interest rate, assuming one year 365 days)

$0,06 / 365=0,000164$

The daily net cash flow variance can be calculated as follows:

$\sigma 2=(2.654) 2=\operatorname{Rp} 7.043 .716$

The lower limit (z) and the upper limit (h) are calculated as follows:

$\mathrm{z}=[3 \times 7.043 .716 /(4 \times 0,000164)] 1 / 3$

$=\operatorname{Rp} 107.123$

$\mathrm{h}=\mathrm{Rp} 107.123 \times 3$

$=\operatorname{Rp} 321.396$ 
The average cash balance is:

$\mathrm{C}=(4 \times \operatorname{Rp} 107.123) / 3$

$=\operatorname{Rp} 142.831$

If we want to set a minimum limit that is worth not 0 , we can add that limit to the value z. Suppose the minimum limit is $\mathrm{L}$, the above formula can be changed as follows:

$\mathrm{Z}^{*}=(3 \mathrm{~b} \sigma 2 / 4 \mathrm{i}) 1 / 3+\mathrm{L}$

$\mathrm{h}=3 \mathrm{Z}^{*}-2 \mathrm{~L}$

$\mathrm{C}=(4 \mathrm{Z}-\mathrm{L}) / 3$

Suppose we set a minimum limit of IDR $100,000.00$ so that the cash balance will never touch the value 0 . The values of $\mathrm{z}, \mathrm{h}$, and $\mathrm{C}$ by entering a minimum limit of Rp. 100,000.00 are:

$\mathrm{z}=\mathrm{Rp} 107.123+\mathrm{Rp} 100.000=\mathrm{Rp} 207.123$ $\mathrm{h}=\mathrm{Rp} 321.396-(2 \times \mathrm{Rp} 100.000)=\mathrm{Rp}$ 121.369

$\mathrm{C}=((4 \times \operatorname{Rp} 207.123)-(\operatorname{Rp} 100.000) / 3=$ Rp 242.831

Cash management can be useful because by doing good cash management the company can stabilize cash conditions and is useful to prevent things that can be detrimental. When a company does not have sufficient cash flow to meet its obligations, cash can help reduce the possibility of significant costs of financial difficulties, such as inefficient asset sales (Qianqian Huang, 2018).

Miller-Orr model applies the determination of the optimal amount of cash balance by involving the process of changes in cash balances that occur periodically and within a certain range, namely between the lower and upper limits. If at a certain time the cash value is above the upper limit, the company can buy securities, whereas if the position of the cash balance is below the lower limit, the company can sell securities to increase the amount of cash. In this case, the research is carried out in SME's if the cash balance is below the UMKM can anticipate by increasing sales or selling existing assets.
However, if the cash balance feels above, then it can be anticipated by making an asset purchase again.

\section{CONCLUSION}

The Miller-Orr model applies the determination of the optimal amount of cash balance by involving the process of changes in cash balances that occur periodically and within a certain range, namely between the lower and upper limits. If at a certain time the cash value is above the upper limit, the company can buy securities, whereas if the position of the cash balance is below the lower limit, the company can sell securities to increase the amount of cash. In this case the research is carried out in SME's, then if the cash balance is below it can be tricked by increasing sales or selling existing assets. However, if the cash balance feels above, it can be dealt with by re-purchasing assets.

Determining the adequacy of cash flows can be calculated using the cash flow adequacy ratio, which is a measure of the ability of a company / organization to generate sufficient cash from operations to cover capital expenditures, investments in inventory. The results of the calculation of the cash flow adequacy ratio provide results that are equal to 1.614. These results need to be interpreted appropriately. A ratio of 1 indicates that SME's can cover cash needs without the need to obtain external funding. External funding can be in the form of loans from banks, loans in the form of capital by people outside of SME's, and so on that are loans from outside SME's. So that it can be interpreted that this shows that the source of internal cash can be sufficient in maintaining the current growth rate of operations of SME's. 
International Journal of Economics, Business and Accounting Research (IJEBAR)

Peer Reviewed - International Journal

Vol-3, Issue-2, 2019 (IJEBAR)

ISSN: 2614-1280

http://www.jurnal.stie-aas/ijebar

\section{BIBLIOGRAPHY}

Baumol, W.J., 1952. The transactions demand for cash: An inventory theoretic approach. Quarterly Journal of Economics 66 (4), 545-556.

Carlos AntonioHerrera-Cáceres, A. (2016). Model predictive control of cash balance in a cash concentration and disbursements system . Journal of the Franklin Institute.

Dr. Mamduh M. Hanafi, M. (2013). Manajemen Keuangan. Yogyakarta: BPFE-Yogyakarta.

Marcelo Botelho da Costa Moraes, M. S. (2014). Evolutionary models in cash management policies with multiple assets. Economic Modelling, 1-7.

M. Badell, J. R. (2005). Optimal budget and cashflows during retrofitting periods in batchch emical process industries. International Journal Production Economics 95, 359-372.

Miller, M.H., Orr, R., 1966. A model of the demand for money by firms. The Quarterly Journal of Economics 80 (3), 413-435.

Orgler, Y.E., 1969. An unequal-period model for cash management decisions. Management Science 16, B77-B92.

Qianqian Huang, F. J.-Y. (2018). Does Short-maturity Debt Discipline Managers? Evidence from Cash-rich Firms' Acquisition Decisions. Journal of Corporate Finance.

Ross, S.A., Westerfield, R.W., Jaffe, J.F., 2002. Administração Financeira Corporate Finance. Ed. Atlas, São Paulo (776 pp.).

Sugiyono. (2013). Metode Penelitian Administrasi. Bandung: Alfabeta.

http://pelakuekonomi.malangkota.go.id 